\title{
Assessing the implementation of Sustainable Development Goals through switching cost
}

\begin{abstract}
An increasing number of corporations are adapting their strategies to include projects aimed at achieving United Nations' Sustainable Development Goals. Nonetheless, the implementation of these projects revives a fifty-year old question about the impact of sustainable activity on corporate financial performance and sustainability outcomes. This paper proposes the analysis of the Switching Costs of sustainable projects as a way to identify areas of improvement for corporate strategies, thus responding to the urgent need for models and assessment tools able to achieve financial and sustainability objectives as claimed by both practice and academia. A conceptual framework relating the Switching Costs of sustainable projects to sustainability and corporate financial performance has been developed and applied in this research to a case-study company, Walmart Mexico and Central America. This paper addresses the challenge of recognising, collecting and gauging the effect of the changes, particularly those of an intangible nature, generated by the sustainable projects.
\end{abstract}




\section{Introduction}

As per the United Nations' Sustainable Development Agenda (2030) released in 2015 that was ratified by 193 countries, "Sustainable Development Goals (SDGs) are the blueprint [for politics, business and society] to [use to] achieve a better and more sustainable future for all"' They include 17 fundamental aspects such as poverty, climate, health and education, among others.

The difficulty of implementing SDG projects in corporate strategies falls down in the over fifty-year literature stream of unsolved 'trade-off' debate on the relationship between Sustainability and Corporate Financial Performance (Friedman, 1962, 1970; Samuelson, 1971). Nevertheless, nowadays, committing to sustainability is not questioned anymore as societal values have changed and these values are reflected by the regulatory developments. As a result, firms are increasingly aware of the risks and opportunities of sustainability in an increasingly competitive environment (Carroll and Shabana, 2010). On one hand, failing to implement sustainability may affect corporate financial performance (CFP), for instance, through fines for compliance breaches or through the detrimental corporate image affecting stock prices (Schaltegger and Burritt, 2018). On the other hand, as ethical indexes gain importance and responsible investment funds bloom, sustainability may represent a new channel for firms to use to raise market capitalisation and external funds (Dam and Scholtens, 2015; Eccles et al., 2014).

Nevertheless, despite the existence of corporate sustainability programmes, the applied sustainability tactics hardly add up to a coherent sustainable strategy (Eccles and Serafeim, 2013). Managers are thus challenged by the pressure of taking and communicating strategic decisions with the dual objective of achieving financial performance and sustainability (Hsu et al., 2013; Silva et al., 2019). For this reason, assessment methodologies such as materiality studies, which are able to reveal a companies' material issues, are becoming increasingly popular, especially with regards to listed companies (Hsu et al., 2013; Khan et al., 2016).

In the specific case of pursuing SDGs, understanding how advantages arise is not straightforward, therefore unveiling the demand for innovative tools and analytical frameworks (Sullivan et al., 2018). In particular, as stated by Caiado et al. (2018), one of the main issues is how to tackle the barriers and challenges that come with operationalising and monitoring the implementation of the 2030 Agenda.

Ultimately, practitioners claim to lack models or tools to use to help managers in making strategic investment decisions in order to gain the dual purpose of sustainability and financial performance (Ludeke-Freund and Dembek, 2017; Maas et al., 2016; Silva et al., 2019). Significant knowledge development is missing out on the effects of implementing 
sustainability, which involves fundamental changes in multiple aspects of the organisation (Bocken et al., 2014). These changes involve not just processes but also values and beliefs, as well as the emotional disposition and motivation of its members (Zollo et al., 2013). Nevertheless, these effects are particularly difficult to assess due to their intangible nature (Funk, 2003; Surroca et al., 2010).

To address this issue, Switching Cost (SC) analysis is proposed in this research to help firms in creating or improving a strategy that is able to successfully implement SDGsoriented projects without compromising the firm's financial performance. In fact, while it is widely recognised in the strategy, economics, and marketing literature that SC is one of the most important factors contributing to business value generation, in the strategic management field, it is also regarded as a crucial factor that helps firms to create and sustain competitive advantages (Hess and Ricart, 2003). Nevertheless, the application of SC analysis to sustainable projects to improve a business-oriented strategy has never been explored.

In this paper, it is argued that switching costs, defined as the costs associated with implementing changes through specific projects, plays a key role in the decision-making process when elements such as sustainability or innovation are incorporated into a financial performance-oriented business strategy.

As noted by Zollo et al (2013), adopting the (sustainability) change initiative as the core unit of analysis, and focusing on some of the theoretically and managerially meaningful dimensions, allows for us to identify the enabling and hindering factors of the transformational processes. Therefore, in this research, the core unit of analysis is corporate SDGs-oriented projects. The meaningful dimensions have been represented by the financial and sustainability performance while the enabling and hindering factors are switching costs.

With regards to sustainability performance, one of the most common practices when measuring a company's ability to achieve sustainability is to consider the environmental, social and governance (ESG) dimensions, represented by the ESG scores generated by various index providers such as Thompson Reuters, MSCI or Bloomberg (Cheng et al., 2014; Eccles et al., 2014 and Ferrero-Ferrero et al., 2016 among others).

To understand the role that SC plays in favouring both financial and sustainability performance, the following questions have been investigated through this research:

RQ1. How can SDGs be better disseminated through the SC analysis of the ESG dimensions?

$R Q 2$. How can SC analysis be applied to a company pursuing both SDGs and financial returns? 
RQ3. How can strategic areas of intervention be revealed to further improve either financial returns or ESG dimensions?

In order to answer the above questions, this paper is structured as follows: the concept and scope of SC as analysed in this work has been explained in Section 2. The theoretical conceptual framework used to assess the firm's strategy and the SC structure of the SDGsoriented projects has been presented in Section 3. The crucial role of the research design adopted for answering the research questions has been explained in Section 4. The application of SC analysis to the case-study in relation to the ESG outcomes and the assessment of the projects has been analysed in Section 5. The implications, applications and contributions of this research to the literature on Sustainability Development and Corporate Financial Performance have been discussed in Section 6. Finally, conclusions and indications for future research have been provided in Section 7.

\section{Switching Cost analysis}

Switching costs is commonly defined as the costs faced by a firm (or an individual) when switching products or providers (Thompson and Cats-Baril, 2002). SC is a complex concept to define because of its multi-dimensional nature and different meanings. The difficulty of conducting SC research is in isolating the situations in which SC could incur and observing the form in which they should exist (Chebat et al., 2011).

The interest in SC analysis for the purpose of this paper is due to the fact that SC is directly related to business financial performance. This is as it represents the cost of changing products, service and suppliers as well as the cost of generating the associated activities, i.e. information searching, contract making, risks etc. Early studies on SC theory such as the one conducted by Monteverde and Teece (1982) focused on Transaction Cost theory (Coase, 1937), which included not only the price of a product on a market, but also other organisational costs due to, for example, uncertainty, searching for information, or contracting. Nevertheless, nowadays, transaction costs cannot be used as a synonym of SC, as layers of complexity and different meanings have been included in the SC definition during the years, making it a multidimensional concept of which transaction costs is just one of the possible categories (Fornell, 1992; Klemperer, 1987). For instance, Nilssen (1992) divides the consumers' switching costs into transaction costs and learning costs. This means that while transaction costs are SC, SC is not exclusively transaction costs.

To identify and understand the definitions and dimensions of the SC construct, over 90 journal papers and books have been reviewed to produce a list of SCs. SC has then been grouped to avoid concepts from overlapping as in Table 1. This permitted the operational data 
collection. For instance, technology-related costs as per Porter $(1980,1985)$, were not analysed as such, but they were analysed as part of wider groups of costs, such as setup and execution, performance and learning costs.

Table 1 - Summary of the Scope of Switching Costs

\begin{tabular}{|c|c|c|}
\hline $\begin{array}{l}\text { Economic \& } \\
\text { Financial } \\
\qquad \underline{\text { Uncertainty }} \\
\underline{\text { costs }}\end{array}$ & $\begin{array}{l}\text { SC which are financially quantifiable } \\
\text { reduced performance and limitations } \\
\text { due to potential risks of uncertainty }\end{array}$ & $\begin{array}{l}\text { Klemperer (1995), Jones et al. } \\
\text { (2002), Whitten and Wakefield } \\
\text { (2006) }\end{array}$ \\
\hline$\frac{\text { Contractual }}{\text { costs }}$ & $\begin{array}{l}\text { - costs of breaking existing contracts or } \\
\text { relationships }\end{array}$ & $\begin{array}{l}\text { - Klemperer (1987), Chebat et al. } \\
\text { (2011) }\end{array}$ \\
\hline Search costs & $\begin{array}{l}\text { - perception of the time and effort of } \\
\text { gathering information prior to the } \\
\text { switching }\end{array}$ & $\begin{array}{l}\text { - Fornell (1992); Patterson and Smith } \\
\text { (2003); Chebat et al. (2011) }\end{array}$ \\
\hline $\begin{array}{l}\frac{\text { Setup and }}{\text { execution }} \\
\underline{\text { costs }}\end{array}$ & $\begin{array}{l}\text { - cost of implementing changes } \\
\text { (facilities, technical support, etc), } \\
\text { including product differentiation costs, } \\
\text { information/communication costs }\end{array}$ & $\begin{array}{l}\text { - Jones et al. (2002); Patterson and } \\
\text { Smith (2003) ; Whitten and } \\
\text { Wakefield (2006); Chebat et al. } \\
\text { (2011) }\end{array}$ \\
\hline Sunk costs & $\begin{array}{l}\text { - perception of investments and costs } \\
\text { already incurred in establishing and } \\
\text { maintaining infrastructures or } \\
\text { relationships }\end{array}$ & $\begin{array}{l}\text { - Jones et al. (2002); Whitten and } \\
\text { Wakefield (2006); Chebat et al. } \\
\text { (2011) }\end{array}$ \\
\hline $\begin{array}{l}\text { Performance } \\
\underline{\text { and time }} \\
\underline{\text { costs }}\end{array}$ & $\begin{array}{l}\text { - perception of the performance } \\
\text { benefits or privileges lost by switching }\end{array}$ & $\begin{array}{l}\text { - De Ruyter et al. (1998); Jones et al. } \\
\text { (2002) }\end{array}$ \\
\hline Procedural & $\begin{array}{l}\text { SC which involve or affect procedures } \\
\text { or processes }\end{array}$ & $>$ Burnham at al. (2003) \\
\hline$\frac{\text { Learning }}{\underline{\text { costs }}}$ & $\begin{array}{l}\text { - perception of the time and effort to } \\
\text { learn a new service routine }\end{array}$ & $\begin{array}{l}\text { - Klemperer (1987); Nilssen (1992); } \\
\text { Fornell (1992); Chebat et al. (2011); }\end{array}$ \\
\hline$\underline{\text { Uncertainty }}$ & $\begin{array}{l}\text { - reduced performance and limitations } \\
\text { due to potential risks of uncertainty }\end{array}$ & $\begin{array}{l}\text { Klemperer (1995), Jones et al. } \\
\text { (2002), Whitten and Wakefield } \\
\text { (2006) }\end{array}$ \\
\hline $\begin{array}{l}\text { Continuity } \\
\underline{\text { costs }}\end{array}$ & $\begin{array}{l}\text { - perception of costs of changing an } \\
\text { existing habit/relation (including } \\
\text { transaction costs) }\end{array}$ & - Chebat et al. (2011) \\
\hline Search costs & $\begin{array}{l}\text { - perception of the time and effort of } \\
\text { gathering information prior to the } \\
\text { switching }\end{array}$ & $\begin{array}{l}\text { - Fornell (1992); Patterson and Smith } \\
\text { (2003); Chebat et al. (2011) }\end{array}$ \\
\hline $\begin{array}{l}\frac{\text { Setup and }}{\text { execution }} \\
\underline{\text { costs }}\end{array}$ & $\begin{array}{l}\text { - cost of implementing changes } \\
\text { (facilities, technical support, etc), } \\
\text { including product differentiation costs, } \\
\text { information/communication costs }\end{array}$ & $\begin{array}{l}\text { - Jones et al. (2002); Patterson and } \\
\text { Smith (2003) ; Wakefield (2006); } \\
\text { Chebat et al. (2011) }\end{array}$ \\
\hline $\begin{array}{l}\text { Performance } \\
\underline{\text { and time }} \\
\underline{\text { costs }}\end{array}$ & $\begin{array}{l}\text { - perception of the benefits or privileges } \\
\text { lost by switching }\end{array}$ & $\begin{array}{l}\text { - De Ruyter et al. (1998); Jones et al. } \\
\text { (2002) }\end{array}$ \\
\hline $\begin{array}{l}\text { Relational \& } \\
\text { Emotional }\end{array}$ & $\begin{array}{l}\text { SC which concern relationships and } \\
\text { affect emotionally }\end{array}$ & $>$ Burnham at al. (2003) \\
\hline$\frac{\text { Continuity }}{\underline{\text { costs }}}$ & $\begin{array}{l}\text { - perception of costs of changing an } \\
\text { existing habit/relation (including } \\
\text { personal relationship loss and } \\
\text { emotional costs) }\end{array}$ & - Chebat et al. (2011) \\
\hline Sunk costs & $\begin{array}{l}\text { - perception of investments and costs } \\
\text { already incurred in establishing and } \\
\text { maintaining relationships }\end{array}$ & $\begin{array}{l}\text { - Jones et al. (2002); Whitten and } \\
\text { Wakefield (2006); Chebat et al. } \\
\text { (2011) }\end{array}$ \\
\hline
\end{tabular}


Performance and time $\underline{\text { costs }}$
- perception of the benefits or privileges lost by switching
- De Ruyter et al. (1998); Jones et al. (2002)

The grouped SC were assigned to three SC types, specifically economic and financial, procedural and relational and emotional, as defined by Burnham et al (2003) and as adopted in successive research studies such as those conducted by Bell et al (2005), Jones et al (2007), and Bhattacharya (2013). Table 1 also highlights that certain SC are multi-dimensional and therefore belong to different types of SC. For example, 'performance and time' costs may belong to all three types of SC; 'economic and financial', 'relational and emotional', and 'procedural'. Similarly, 'setup costs' or 'search costs' may be 'economic and financial' costs and/or 'procedural' costs.

The literature review also revealed that over the years, a large stream of research has focused on the firms' strategic moves with respect to the consumers' SC, partially obscuring the effects that the costs play internally within the firm as a result of its strategic decisions and the active role that the firm can undertake in managing them. Nevertheless, it is particularly important to focus on this aspect as an adverse relation exists between the firms' SC and CFP, as pointed out firstly by transaction-cost theorists such Coase (1939) and Williamson (1981) and lately, by Porter (1985), who claim that a corporate financial strategy needs to minimise the SC incurred by the firm itself. In light of this, the conceptual framework presented in the next section reintroduces SC analysis from a firm's perspective.

Nonetheless, it is noted in the literature that changes due to the implementation of sustainability also creates benefits for the organisation (Byl and Slawinski, 2015; Markman et al., 2016). In particular, it has been remarked that the creation of value (beyond just its economic sense) occurs when benefits exceed costs and therefore both benefits and costs should be taken into consideration (Barroso and Picón, 2012; Porter and Kramer, 2002).

In this regard, it is claimed that switching benefits as per Nilssen (1992) is the opposite of switching costs or, using Hellmer (2010)'s words, that 'negative switching costs' are 'switching benefits' (SB). This reflects the fact that any change introduced to the organisation (including those created by the sustainable activity) may generate positive or negative effects, both of which need to be considered when assessing the created value.

Thus, in this paper, it is necessary to highlight and consider the possibility of bringing not just costs but also benefits into the organisation while a change (i.e. switching products or suppliers) is taking place. That is to say, although the majority of the literature refers to SC in 
the proposed conceptual frameworks discussed so far, when it comes to the detailed SC analysis, it is concerned with both SC and SB.

\section{Conceptual research framework}

Based on the literature on Sustainability and Corporate Financial Performance, the conceptual framework as developed in this paper has been shown in Figure 1. The strategy objective is the combination of three variables, namely CFP, the sustainable activity (here it is the SDG-oriented projects) and its outcome (the sustainability performance, here represented by the ESG score).

In particular, according to the theory of slack resources, the stronger the CFP that a firm achieves, the more sustainable commitments that the firm has and, in turn, the higher the level of investment in sustainability that projects can be (Orlitzky et al., 2003; Surroca et al., 2010, among the others). In addition, as per Ferrero-Ferrero et al (2016), a company's commitment and effectiveness towards the creation of a consistent competitive advantage in the ESG dimensions constitutes an intangible value that leads to improvements in corporate performance. Nonetheless, the positive relationship between the ESG score and financial performance also reflects on the access to new capital (Dam and Scholtens, 2015; Eccles et al., 2014).

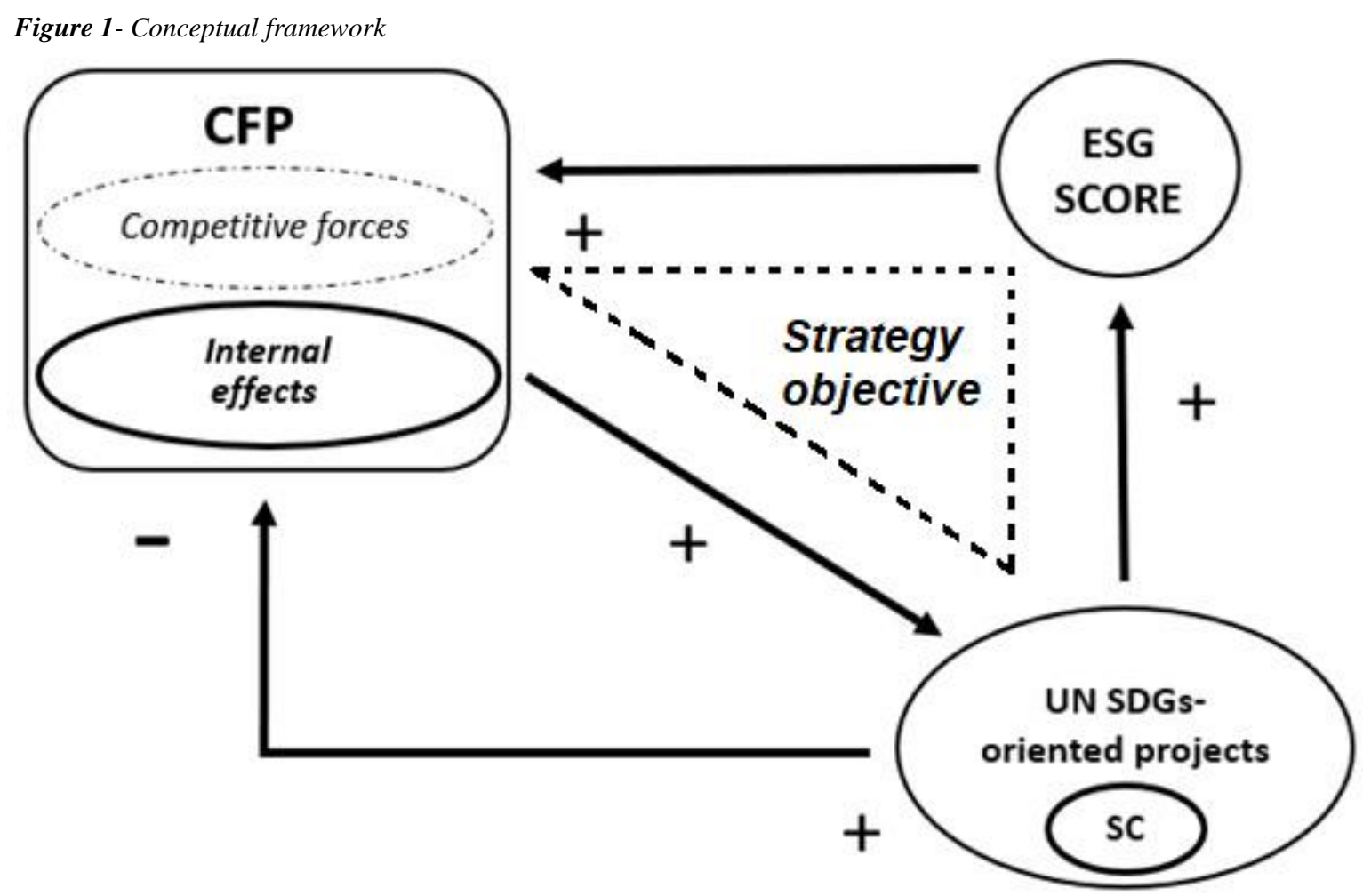

The lower part of the diagram on SC introduces new considerations for the full achievement of the objective of the strategy. In this regard, it is important to highlight that while SDGs- 
oriented projects have a direct positive input concerning sustainability performance (and therefore the ESG Score), the effects on CFP are not as direct. There are many factors affecting CFP, among which are the competitive forces mentioned by Porter's Five Forces (1985) (threat of new entrants, substitutes, the customers' power, the suppliers' power and industry rivalry, among the others). Nevertheless, while extensive research on this aspect has been conducted over the years, this work addresses the need for academics to conduct further research on the firm's SC, as mentioned in Section 2. The framework thus highlights the negative relationship between a firm's SC and its CFP (Porter, 1985).

The above described conceptual framework allows us to analyse the SC structure of a company to detect areas of improvement for the corporate strategy in order to achieve high sustainability and CFP. By suggesting areas of intervention, the framework helps firms to identify more effective ways of investing money into sustainability projects and reducing the amount of wasted resources to achieve their ultimate strategic objectives.

\section{Research Design}

There are two main challenges in the study of SC and therefore in the development of the tools or models used for SC analysis (Burnham et al., 2003; Hess and Ricart, 2003). First of all, there is a lack of consistency or comprehensive typology as well as confusion in terms of conceptualising and categorising the SC construct. Second, there is the difficulty of collecting and measuring SC, which is strictly related to the first. SC is very specific to each organisation and a database does not exist. The issue of measuring SC is due to its multi-dimensional nature, as mentioned in Section 2, which adds complexity to the challenge of defining and recognising the SC construct, spanning into numerous scales, degrees and perspectives which makes it difficult to isolate and gauge the various components of SC (Burnham et al., 2003; Chebat et al., 2011). In addition, while financial costs are quantifiable in nature, the relational (also called 'social') or procedural costs are much more difficult to reveal and measure (Stole, 2007).

To overcome the challenges that hinder the investigation of the questions that are the object of this work, the research design undertaken has been summarised in Figure 2. The results have then been shared with the participating firm, which approved the publication of this paper. 


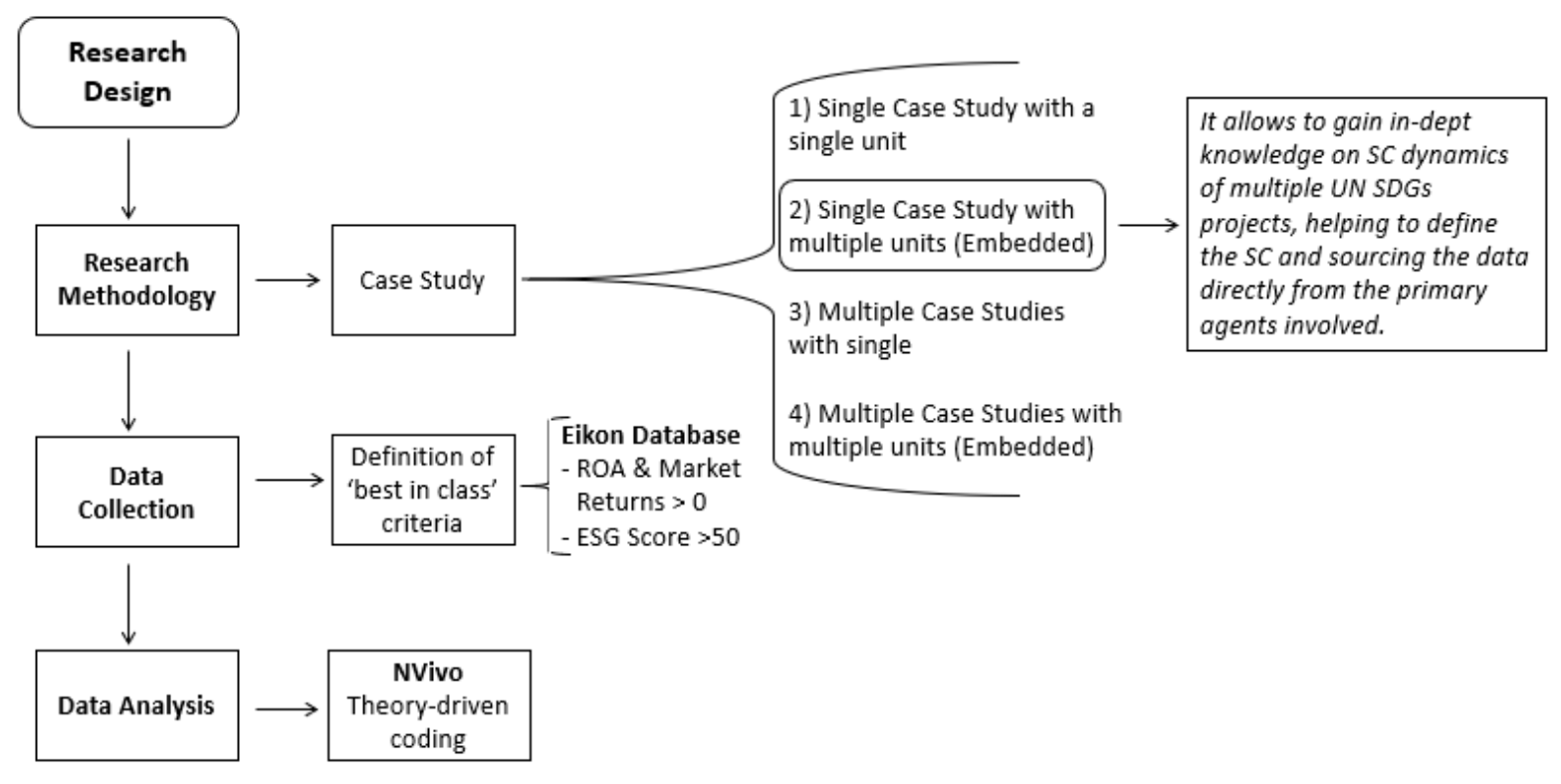

\subsection{Case Study Research}

The choice of using a case study research methodology is crucial in this work to collect the kind of information needed to answer the research question by its epistemological implications. In fact, when looking to build knowledge and understanding the dynamics of a still unexplored field such as the relationship between the SC of sustainable projects and CFP, the case study methodology favours an in-depth understanding of complex issues such as any organisational and managerial dynamics for its ability to answer the 'how' research questions (Swanborn, 2010; Yin, 2018).

As mentioned by Yin (2018), there are four different research designs with regards to case study research depending on the depth and breadth that is needed to answer the research question: single case with just one unit of analysis (Type 1), single-case which is 'embedded', i.e. with multiple units of analysis (Type 2), multiple case studies with a single unit of analysis (Type 3) and 'embedded' multiple case studies (Type 4). The four case study types correspond to different implications in terms of reliability and the generalisation of any claimed results, with the weaker being Type 1 and the stronger being Type 4.

As the purpose of this research is not to conduct a comparative or inferential study but rather to explore SC analysis in light of the developed conceptual framework, Type 2 has been chosen over the other options. The 'embedded case-study' consists of a case (company) with multiple units of analysis (projects), which has been chosen in this study as the 'best-in-class' to represent a critical case. The critical case is part of a purposive sampling based on a judgement about a specific population, which in this research consisted of the ESG and CFP criteria as discussed in the following section. Purposive sampling is usually preferred in explorative research to random sampling, which instead typically characterises inferential 
studies (Lavrakas, 2008). According to Yin, the original phenomenon of interest (the company) becomes the context and not the target of study, which instead focuses on applying SC analysis to SDGs-oriented projects.

As mentioned by Easton (2010), the knowledge claims of case study research are often attacked due to their lack of generalisability. Nevertheless, it is important to remark as per Yin (2018) that case studies, like experiments, are generalisable to theoretical propositions as the researcher's goal is to expand and generalise theories (analytical generalisation) rather than to enumerate frequencies (statistical generalisation).

\subsection{Case-study selection criteria}

As noted by Auerbach and Silverstein (2003), different sampling strategies lead to different implications and what is the most appropriate depends on the research purpose. In selecting the critical sampling, a list of 'best-in-class' with a high ESG score and high CFP was produced through Thompson Reuters' Eikon according to the following criteria:

- CFP was represented by positive accounting measures, specifically ROA (return on assets), ROE (return on equity) and positive market measures such as total returns. The choice of CFP variables follows a number of studies that have considered both accounting and market indicators to capture all sustainability benefits (Dam and Scholtens, 2015; Stankevičienè and Čepulytė, 2014; among the others).

- Sustainability performance is represented by an ESC Score > 50. This benchmark figure corresponds to the firms' risk rating of A and B ranges as per Thompson Reuters (2019), representing the low risk of negative financial impact due to poor sustainability performance. Assigned by credit rating agencies such as Standard \& Poor's, Moody's and Fitch Ratings, these scores can be considered a further indication of good practice, particularly in terms of corporate governance as they reflect the company's ability to pay back debts and therefore they are an indicator of financial stability.

The company participating to this study, Walmart Mexico and Central America, is one of only 18 public retail companies worldwide to meet the 'best-in-class' criteria. The company is characterised by a series of achievements in terms of financial as well as ESG performance as shown in Table 2. 
Table 2 - Sustainability and Financial Criteria for Walmart Mexico and Central America (Thompson Reuters Eikon, FY data)

\begin{tabular}{|ccccccc|}
\hline \multicolumn{7}{|c|}{ Sustainability and Financial Criteria } \\
\hline Company name & $\begin{array}{c}\text { ESG Score } \\
\text { (Average) } \\
2015-2017\end{array}$ & $\begin{array}{c}\text { ESG Score } \\
\text { (Average) } \\
2017\end{array}$ & $\begin{array}{c}\text { ESG Score \% } \\
\text { Change } \\
\text { (Average) } \\
\text { 2015-2017 }\end{array}$ & $\begin{array}{c}\text { ROA } \\
\text { (Average) } \\
2017\end{array}$ & $\begin{array}{c}\text { ROE } \\
\text { (Average) } \\
2017\end{array}$ & $\begin{array}{c}\text { Total } \\
\text { Re turn } \\
\text { (Average) } \\
2015-2017\end{array}$ \\
\hline $\begin{array}{c}\text { Wal Mart de Mexico } \\
\text { SAB de CV }\end{array}$ & 77.32 & 79.86 & $3.3 \%$ & $10.5 \%$ & $17.9 \%$ & $22.2 \%$ \\
\hline
\end{tabular}

\subsection{Data collection method}

The research was conducted through interviews applied in an inductive and abductive investigation (descriptive, exploratory or explanatory). This is because it allows for the researcher to collect targeted data on a chosen topic in an insightful way, providing perceived causal inferences and explanations (Yin, 2018). This method is particularly appropriate to gather information when the participants are informed of the facts or where they can provide historical insights, giving control over the lines of questioning (Creswell and Creswell, 2018). Interviews also go beyond the content and operational limitations of documentary research, such as understanding the effects and provision of the feedback on the right language to use with the participants, or when the research aim is to identify gaps between strategic decisions and their effects (Saunders et al., 2015). The high degree of sensitivity to the context, as is the case of corporate projects and their SC, is rightfully regarded as a crucial advantage of qualitative interviews over the standardised survey method (Bogner et al., 2009).

Among the different types of interviews, semi-structured ones are the most suitable to use when collecting data on SC in order to further understand their strategic aspects. This is because the questions are based on pre-defined (yet flexible) coding, thus allowing for the information gathering to be done in an organised, comparable way. The open-ended and conversational nature of this kind of research method highly favours deep understanding, helping the researcher to detect relationships between key concepts and key players (Creswell and Creswell, 2018; Saunders et al., 2015).

The information collected through the interviews was integrated, complemented and verified with secondary data (documents), as in Table 3.

Table 3- Documentary Material

\begin{tabular}{|l|l|l|l|}
\hline Document Title & Type & Source & Year \\
\hline $\begin{array}{l}\text { - Corporate Social } \\
\text { Responsibility } \\
\text { Management }\end{array}$ & PPT Presentation, & Company by email & 2017 \\
\hline
\end{tabular}




\begin{tabular}{|c|c|c|c|}
\hline $\begin{array}{l}\text { - Central America } \\
\text { (Responsibility) } \\
\text { Factsheet }\end{array}$ & Factsheet & $\begin{array}{l}\text { Company Website } \\
\text { https://corporate.walmart.com/media- } \\
\text { library/document/central-america- } \\
\text { market-fact-sheet-october- } \\
\text { 2018/_proxyDocument?id=00000166- } \\
\text { 7833-dffa-a767-78f726ea0001 }\end{array}$ & 2018 \\
\hline $\begin{array}{l}\text {-General } \\
\text { Information }\end{array}$ & Webpage & $\begin{array}{l}\text { Company Website } \\
\text { https://corporate.walmart.com/our- } \\
\text { story/our- } \\
\text { business/international/central-america } \\
\underline{\text { https://www.walmart.com.mx/ }}\end{array}$ & $2016-2018$ \\
\hline $\begin{array}{l}\text { - Global Women } \\
\text { Empowering }\end{array}$ & $\begin{array}{l}\text { PPT Presentation, } \\
\text { Project Information }\end{array}$ & $\begin{array}{l}\text { Department of Suppliers Development } \\
\text { by email }\end{array}$ & 2017 \\
\hline $\begin{array}{l}\text { - Projects } \\
\text { clarifications } \\
\text { (reverse economy) }\end{array}$ & Email & Company by email & 2017 \\
\hline $\begin{array}{l}\text { - Recycling PET } \\
\text { Bottles \& } \\
\text { Aluminum }\end{array}$ & $\begin{array}{l}\text { PPT Presentation, } \\
\text { Project Information }\end{array}$ & $\begin{array}{l}\text { Department of Reverse Economy by } \\
\text { email }\end{array}$ & 2016 \\
\hline - Small Supplier & $\begin{array}{l}\text { PPT Presentation, } \\
\text { Project Information }\end{array}$ & $\begin{array}{l}\text { Department of Suppliers Development } \\
\text { by email }\end{array}$ & 2017 \\
\hline $\begin{array}{l}\text { - Strategy for } \\
\text { Corporate } \\
\text { Responsibility }\end{array}$ & $\begin{array}{l}\text { Financial and } \\
\text { Corporate } \\
\text { Responsibility Report }\end{array}$ & $\begin{array}{l}\text { Company Website } \\
\underline{\text { https://corporate.walmart.com/2018grr/ }}\end{array}$ & 2018 \\
\hline
\end{tabular}

While the units of analysis are the company's SDGs-oriented projects, the unit of the data collection itself is made up of individuals. Given the importance of interviewing the sources who are the most knowledgeable on the discussed projects or who have a major impact through their actions, as suggested by Bogner et al (2009), Heads of Projects, Heads of Departments and Project Managers were chosen as the interviewees and therefore as the data sources.

The qualitative nature of the collected data was then examined through quantitative, descriptive analysis. In fact, fairly large quantities of data can normally be processed as part of a qualitative content investigation, allowing for quantitative stages to be built into the analysis (Flick et al., 2004). In fact, data collected through both documentary research and interviews can be processed using coding and converted to quantitative data (Auerbach and Silverstein, 2003).

\subsection{Questionnaire design}

The list of investigated SCs has been reported in Table 4 in relation to the number of questions submitted to the interviewees (see the questionnaire in Table 5).

Table 4 - Types of switching costs revealed by questions

\begin{tabular}{|l|}
\hline Switching Costs \\
\hline$\underline{\text { Economic \& Financial }}$
\end{tabular}


Uncertainty costs

Contractual costs

Search costs

Setup costs

Sunk costs

Performance costs

Procedural

Learning costs

Uncertainty costs

Continuity costs

Search costs

Setup costs

Performance costs

$\underline{\text { Relational \& Emotional }}$

Continuity costs

Sunk costs

Performance costs
$1,2,3$

1, 2, 3, 7

$2,3,4,5$

$1,2,3$

$1,2,3,7$

$1,2,3,5$

$2,3,4,5$

$2,3,4$

$2,3,4,5,6,7$

$2,3,4,5$

$2,3,4,5$

$2,3,4,5$

2, 3, 6, 7, 8

$2,3,6,8$

$2,3,5,6,8$

This phase of the research design is particularly important for this study to create codes prior to data collection according to the following steps (Given, 2008):

1. The concepts were developed in advance (see Figure 1, Section 3) and the categories and their codes were derived from existing theory or borrowed from the existent literature.

2. The predetermined categories were used to structure the data that was collected (see Table 1 and Table 4).

3. The questionnaire was pre-coded. The categories, in addition to their definitions and properties, have been clearly laid out in a codebook specific to the study (Table 1).

Given the challenge of revealing the 'non-quantifiable' component of SC, particularly the relational and procedural costs as claimed by Stole (2007), SC has been investigated by collecting the agents' SC perceptions following the methodology adopted in previous literature such as the studies conducted by Burnham et al (2003), Bell et al (2005), Jones et al (2007) and Chebat (2011). The questions submitted to the interviewees have been reported in Table 5. The interviews lasted an hour and they were audio-recorded and transcribed verbatim. 
Table 5 - Semi-structured Interview Questions

\section{Semi-structured Interview Template}

\author{
ORGANISATION \\ REGION OF HEADQUARTER \\ PARTICIPANT ROLE \\ DEPARTMENT \\ DURATION SESSION
}

\author{
Walmart Mexico \& Central America \\ Mexico \\ Head of function/Manager \\ Corporate Governance \\ 1 hour
}

\section{SDGs-oriented Project Questions}

1. Did any of those projects require a financial investment from your department?

2. Which of the sustainability projects had a major effect on your department and why?

(e.g. employee involvement, financial impact, operation disruptions, improvements of any kind, department dynamics etc).

3. How do these projects fit into the overall departmental strategy?

4. What kind of projects that aim to improve sustainability do you consider to be more in line with your department's strategy? Do these projects create any issues in your department that you can see?

5. Have these projects required a time commitment from your employees? (e.g. training/learning, setting up facilities, commuting, research into a new product or provider, delays and formalities/bureaucracy)

6. Did these projects change any habits or have an emotional impact on the employees in your department?

7. Did any of the activities create any benefits beyond their purpose or caused benefit losses?

(e.g. lost preferential treatment from suppliers, fees for breaking existing contracts)

8. Did any of these projects create changes in existing relationships among colleagues internal and external to the department, suppliers or customers?

(e.g. benefits, costs, other...)

\subsection{Characteristics of collected data}

A total of 6 interviews were conducted and 16 embedded cases (SDGs-oriented projects) were discussed with the company. Each interviewee, specifically a Head of Department or Key Project Manager, was asked to choose 2 or 3 projects for which he/she is responsible.

Table 6 - Walmart's Strategic Objectives, Areas of Responsibilities and Key SDGs-oriented Projects.

\begin{tabular}{|l|l|l|}
\hline Strategy Objective & $\begin{array}{l}\text { Areas/Departments of } \\
\text { Responsibility in the Company }\end{array}$ & Key SDGs-oriented Projects \\
\hline - Sustainability & Reverse Economy & Recycling PET Bottles \& Aluminum \\
\cline { 3 - 3 } & & Recycling Cans \\
\hline \multirow{2}{*}{ Customers } & Marketing & Food Bank \\
\cline { 3 - 3 } & & Small Supplier \\
\cline { 3 - 3 } & \multirow{2}{*}{ Suppliers Development } & Sustainability Information \\
\hline & & Small Supplier (1) \\
\hline$\bullet$ Governance & Corporate Governance & CSR Annual Report \\
\cline { 3 - 3 } & & CSR Analysis \\
\hline
\end{tabular}




\begin{tabular}{|l|l|l|}
\hline \multirow{2}{*}{ Employees } & & Sustainable Investors Relations \\
\hline & & Cultural Promotion \& Integration \\
\cline { 3 - 3 } & & Gender Equality \\
\cline { 3 - 3 } & Foundation & Disability \\
\hline & & Food Bank (1) \\
\hline & & Voluntary Work \\
\cline { 3 - 3 } & & Small Supplier (2) \\
\hline
\end{tabular}

Table 6 describes the strategic objectives as per the company's Sustainability Report (first column), the business areas or the departments involved in the interviews (second column) and the respective key SDGs-oriented projects discussed by each interviewee (third column). The grey colour in the third column shows the interdepartmental projects, i.e. projects carried out by more than one department or business area as part of wider programmes.

\subsection{Coding, interpreting, and analysing}

The SCs as listed in Table 4 were assigned in the form of codes to sections of the transcribed interviews, thus allowing the researcher to interpret the content. NVivo software was used to reorganise the text and report back under the assigned codes. Using the reorganised transcripts, the text was systematically analysed.

The following criteria were used in the process of coding and interpreting:

- The interview transcripts were coded through constant comparative analysis.

- Theory-driven coding was preferred to open coding, given the specific intent of uncovering SC in this research.

- Codes were applied in the text when the content was closely related to the specific nature of the SC.

- SC was collected according to the 3 macro-groups of 'financial and economic, 'procedural', and 'relational and emotional', as per Burnham et al (2003).

- Each project was tagged with the most relevant ESG dimension according to the number of codes.

- Each ESG dimension was analysed in terms of SC. The total impact (or number of coded text) was divided by the number of projects related to the particular dimension to avoid the bias created by samples with a different number of projects and therefore accounting for the average impact by project.

- Two-level codes, specifically 'SC' and 'Types of SC' were used, as the same SC may belong to different types of SC.

- When the SC effect is reversed (i.e. positive impact), it is coded as switching benefit (SB), e.g. 'setup' SB.

- SC impact is measured by the number of codes appearing in the interview text. 
- The net effect of SC (or SB), as NSC (or NSB), is measured as [SC-SB].

- Financial figures were coded based on the interviewees' perception as with all of the other SC.

\section{Analysis}

The conceptual framework explained in Section 3 allows for the analysis of SC from different levels and perspectives. First of all, the SC data can be explored in relation to the ESG dimensions in order to understand the existing relationships and to allow for interpretation according to the framework. Secondly, the analysis of the SC data at the aggregate level allows for us to understand what is the most impactful as well as the most common issues for the organisation. In addition, the SC data analysed at project level allowed the researcher to compare the effects of different projects on the organisation overall. For the purpose of assessing SC, the data has been summarised in a map, thus aiming to facilitate a clear understanding of project strengths such as SB and areas of future intervention for SC reduction.

\subsection{The SC-ESG relationship}

To answer the first question on how SC is related to ESG, the projects discussed during the interviews have been coded following the process described in Section 4.4. The main ESG dimension by project and the number of codes has been reported in Table 7 .

Table 7 - ESG main dimension by SDGs-oriented project

\begin{tabular}{|c|c|}
\hline Key SDGs-oriented Projects & ESG (\# codes) \\
\hline Recycling PET Bottles \& Aluminum & $E, G(7)$ \\
\hline Recycling Cans & $E(6)$ \\
\hline Sustainability Information & $G(2)$ \\
\hline Global Women Empowering & $G(3)$ \\
\hline CSR Annual Report & $G(4)$ \\
\hline CSR Analysis & $G(5)$ \\
\hline Sustainable Investors Relations & $G(7)$ \\
\hline Cultural Promotion \& Integration & $S, G(3)$ \\
\hline Gender Equality & $S(9)$ \\
\hline Disability & $S(5)$ \\
\hline Voluntary Work & $S(4)$ \\
\hline Small Supplier & $S(9)$ \\
\hline Food Bank & $S(9)$ \\
\hline $\begin{array}{l}\text { TOT. \# E-PROJ } \\
\text { TOT. \# S-PROJ } \\
\text { TOT. \# G-PROJ }\end{array}$ & \\
\hline $\begin{array}{l}\text { Legend: Sustainability key project } \\
\text { dimension, Environmental (E), So } \\
\text { The number of codes is reported in }\end{array}$ & $\begin{array}{l}\text { I by their main ESC } \\
\text { ind Governance }(G) \\
\text { lesis. }\end{array}$ \\
\hline
\end{tabular}

Figure 3 shows the effect of net switching costs (NSC) measured as the number of coded texts and the difference between SC and SB for each ESG dimension. As mentioned in Section 4.4, each dimension has been divided by the corresponding number of projects. This analysis is aimed at addressing the effect that each SC type has over the three ESG dimensions that are 
frequently used in academic research to gauge sustainable activity with respect to economic and/or financial performance (e.g. Eccles et al., 2014; Ferrero-Ferrero et al., 2016).

Figure 3 - NET SC types by ESG Dimensions (Environmental, Social and Governance)
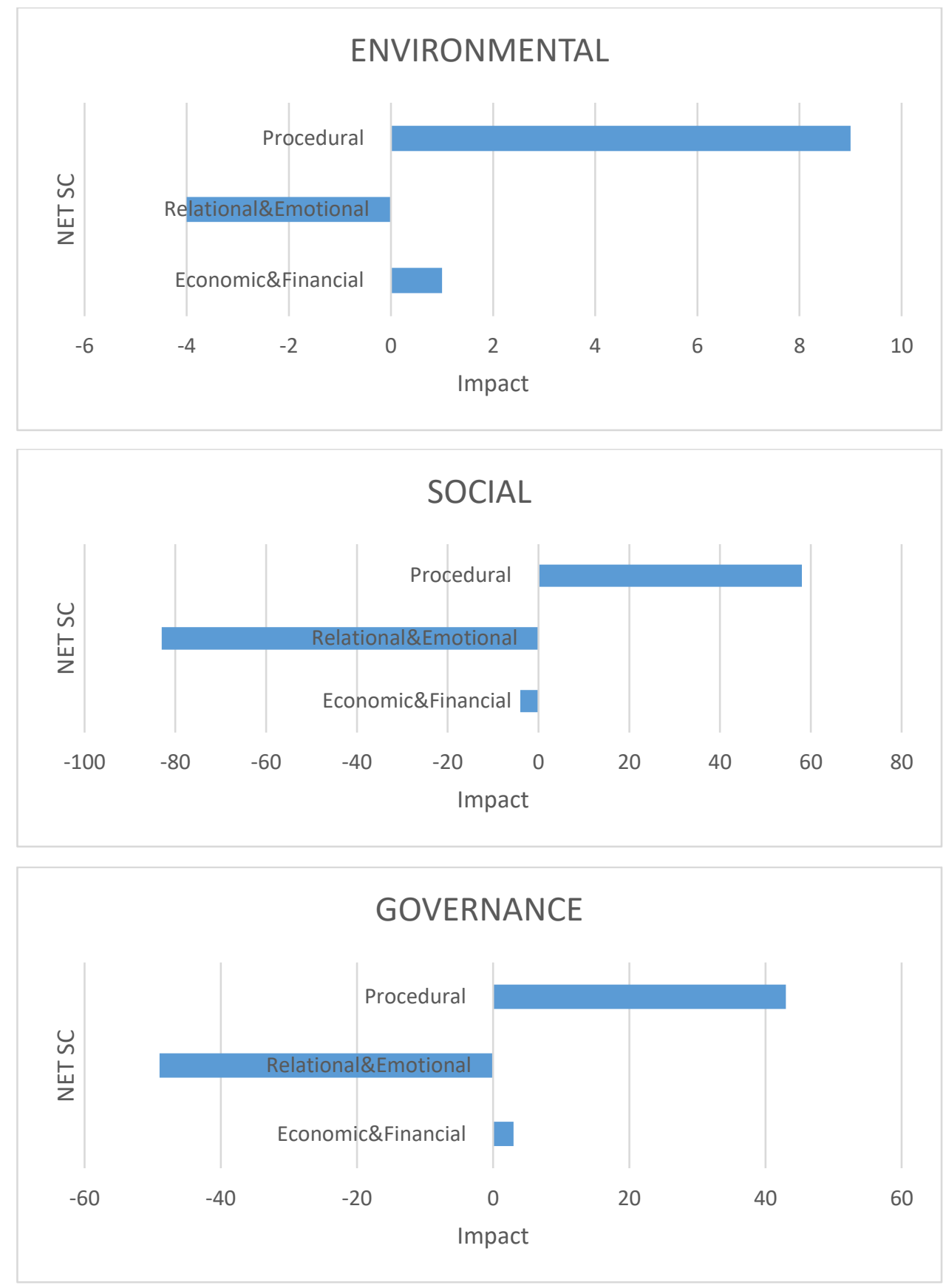

What appears evident is the impact of the procedural costs of the projects in all three ESG dimensions. While the positive impact of the relational and emotional component is particularly evident in social projects, the economic and financial component varies depending on the ESG dimension. In fact, environmental and governance projects are perceived to produce a cost for the organisation while social projects are perceived as creating a financial or economic benefit, 
such as using the resources that already exist, producing savings or simply not requiring any extra financial commitments.

\subsection{SC at aggregate level}

The analysis of Walmart's SC structure was conducted by considering the impact of SC accounted for by the number of codes across all projects. As per the conceptual framework, SDGs-oriented projects produce effects on CFP, which is negative when SC are positive and vice versa. Figure 4 shows that the implementation of sustainable initiatives is associated to two specific switching costs, 'setup and execution' and 'performance and time'.

Examples of 'setup and execution' costs revealed by the interviews include the human resources employed in managing the containers to recycle the bottles, gathering food in store for the Food Bank project, the organisation of the advertisements for the different sustainability initiatives, the collection of customer feedback, cleaning activities after any voluntary work etc. In certain cases, such as in Recycling PET Bottles and the Aluminum project, the containers do not require being moved, therefore there is a 'saving', i.e. Setup and Execution SB. Similarly, the Food Bank project uses an automated operational system that has been implemented for years. As a result, there is no extra 'setup and execution' cost in terms of running the project and therefore this is accounted for as a Setup and Execution SB.

'Performance and time' costs and benefits have the same impact. In fact, certain projects such as a Small Supplier Development require personalised attention from Walmart's Suppliers Development team, thus determining an important cost in terms of 'performance and time'. Nevertheless, for the same programme, a different team such as Marketing is not wasting any 'performance and time' as advertising the project is not just part of its 'sustainability duties'. This is as it naturally falls under the department's objectives. As no additional time is required, this shows the team's ability to streamline the introduction of sustainability within the existing processes, without compromising the overall performance and the employees' time. 
Figure 4 - Impact of Switching Costs and Benefits in Walmart

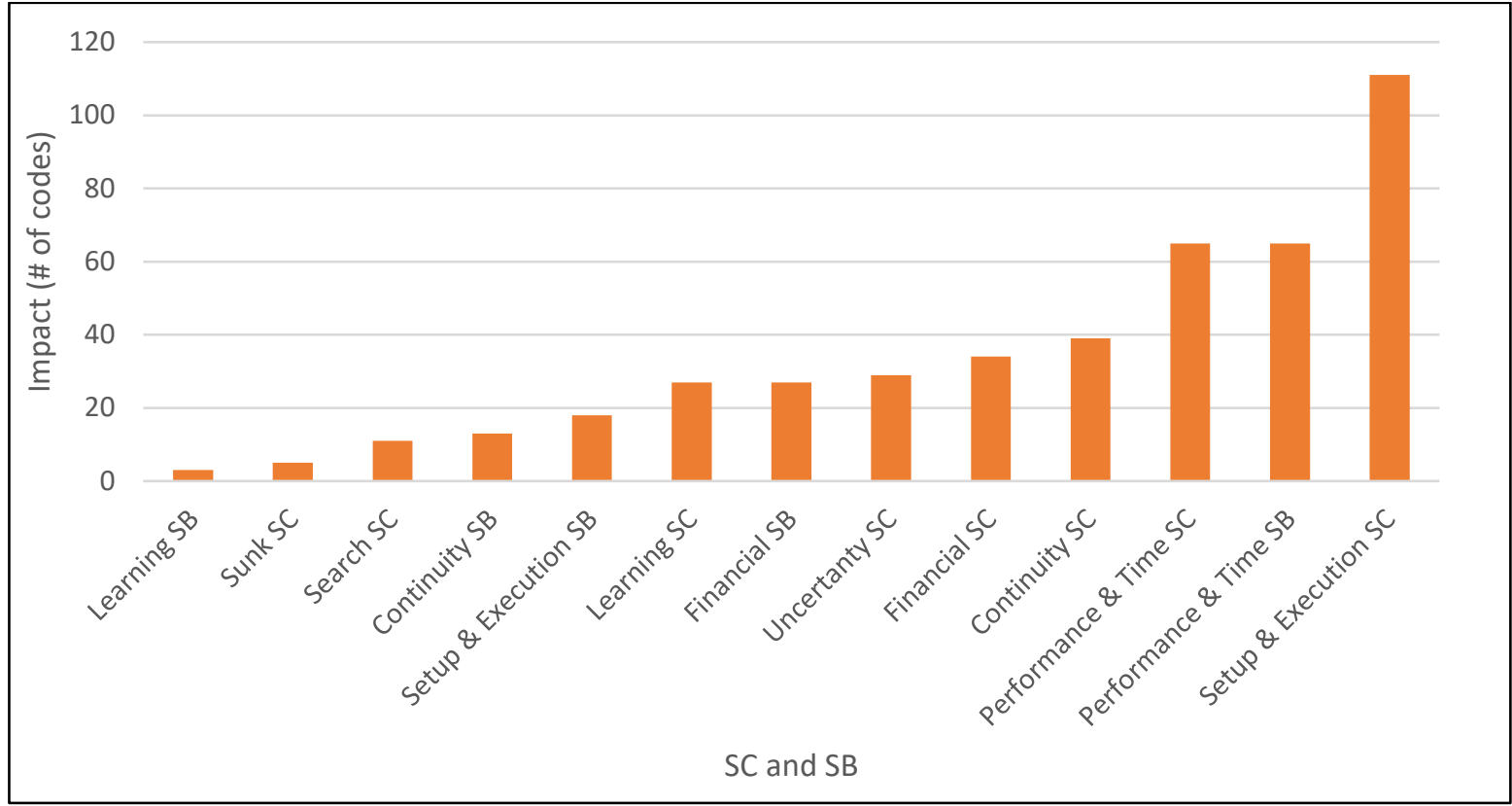

Figure 5 shows the net effect calculated by SC minus SB in across the projects, indicating the major effects on the organisation. In light of this, the NSC which most affects the organisation is net 'setup and execution', with a $48 \%$ impact on the sustainability projects overall. It is also important to note that every SC is more than just the respective benefit, with the only exception being 'performance and time' impact. This is as SC equals SB and therefore it does not appear on the chart. 'Uncertainty' is the second most impactful cost. This is due to the fact that there is no respective benefit.

Figure 5 - Net Switching Cost Impact

\begin{tabular}{|c|c|}
\hline $\begin{array}{l}\text { Legend: } \\
\text { - Net Switching Cost Effect is [SC-SB] } \\
\text { - The circle represents the impact of SC as per number of codes }\end{array}$ & $\begin{array}{l}\text { - Continuity } \\
\text { - Financial } \\
\text { - Learning } \\
\text { - Performance \& Time } \\
\text { - Search } \\
\text { - Setup \& Execution } \\
\text { - Sunk } \\
\text { - Uncertainty }\end{array}$ \\
\hline
\end{tabular}

Considering SC presence, i.e. how SC is distributed among the projects, Figure 6 shows that 'performance and time' costs are not only the most relevant issue as seen in Figure 4, but that 
they are also the most common. This is as they are present in all 16 analysed projects. Nevertheless, benefits in terms of 'performance and time' are present in almost all projects (15 out of 16). Similarly, almost every project experienced 'setup and execution' costs. It is also interesting to note that 'sunk' and 'search' costs are more specific to certain projects (respectively in 3 and 5). For example, the Disability project presents 'sunk' costs where the modification of existing infrastructures is required. For the Sustainability Information project, the marketing department incurs 'search' costs to find out which sustainability themes are important to customers.

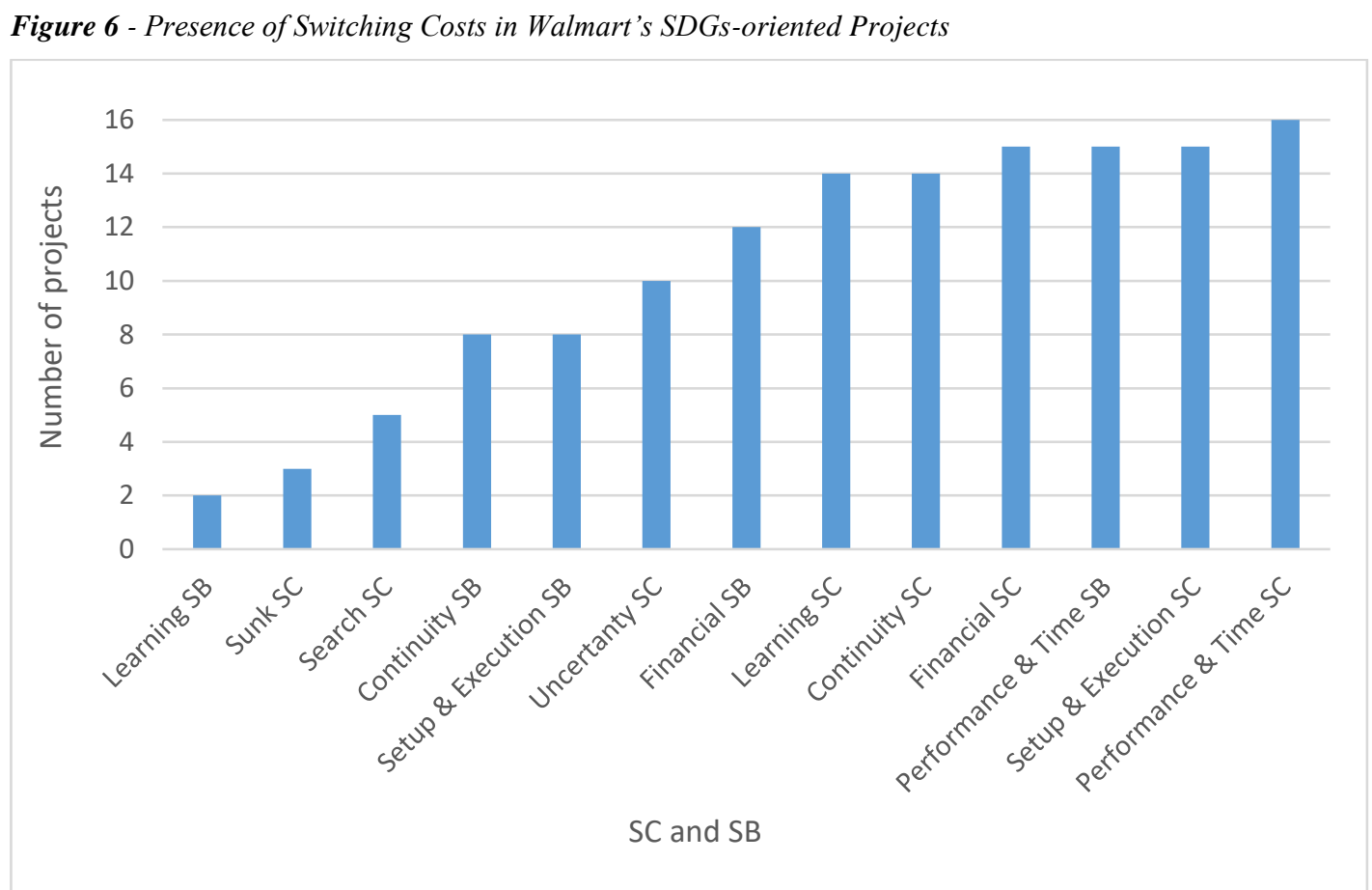

Figure 7 compares the negative effect of SC to the positive effect of SB, aggregating the impact (number of codes) by SC type as per Burnham et al (2003). The negative effect of the 'procedural' costs should not be a surprise, as it is largely influenced by the 'setup and execution' component. The 'economic and financial' costs and benefits are equal, as if it is accepted that sustainability requires certain financial investments, they are paying themselves back in the long-term. As previously explained, it is important to remark that 'economic and financial' costs are coded considering SC perceptions as are all the other costs and not as accountancy figures. 
Figure 7 - Impact by Switching Costs Type.

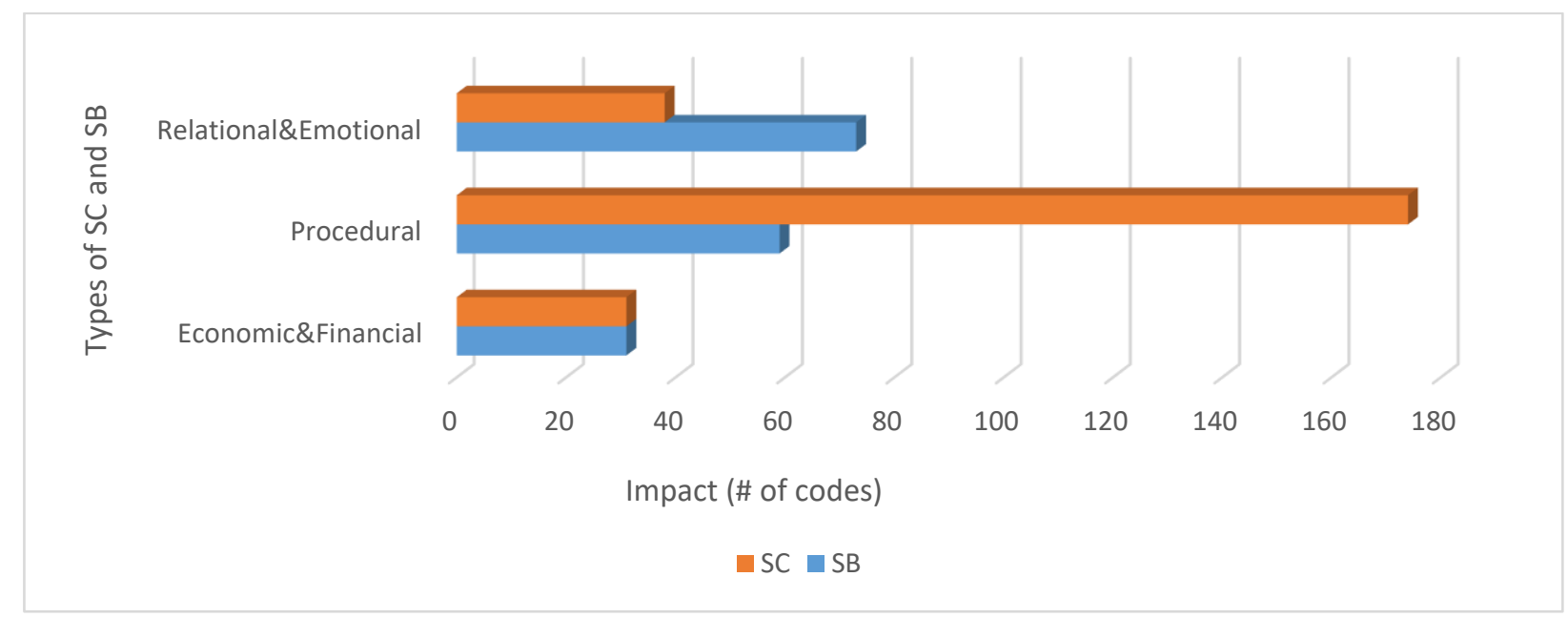

The 'relational and emotional' dimension is the only one to show an excess of SB. This reflects the emotional involvement of employees in the Voluntary work project, the willingness to emotionally connect with the customers in the Sustainability Information project, or the gratitude of small suppliers for the received help in relation to growing their business. Nevertheless, the positive effect is almost halved by SC. The challenge of the Recycling Can project involves customers or a conflict of objectives between the sustainability department and other departments such as operations or marketing.

\subsection{Project mapping}

According to the conceptual framework in Section 3, to encourage CFP, a company should reduce its SC. The map reported in Table 8 shows the net effects of SC and SB at the project level, thus helping to visualise and detect areas of SC presence and possible interventions in order to further boost CFP.

Table 8 displays interesting considerations. First of all, the Global Women Empowering project reveals only one NSC ('learning') and positive financial benefits. This is due to the specificity of the project, which is a part of a global programme. It therefore requires less involvement from Walmart Mexico and Central America. This suggests that projects organised at the global brand level implemented regionally have lower SC than projects that are totally run regionally. Employee-related projects seem to be particularly effective in terms of 'performance and time' as revealed by NSB. The opposite situation is the Voluntary Work project. This is where employees subtract more time from their duties, despite the possibility of freely applying their skills. 
Table 8 - Map of Net Switching Costs (or Benefits) by SDGs-oriented Project.

\begin{tabular}{|c|c|c|c|c|c|c|c|c|}
\hline Projects $\downarrow \mid$ NSC or NSB $\rightarrow$ & Continuity & Financial & Learning & $\begin{array}{c}\text { Performance } \\
\text { \& Time }\end{array}$ & Search & $\begin{array}{c}\text { Setup \& } \\
\text { Execution }\end{array}$ & Sunk & Uncertainty \\
\hline $\begin{array}{l}\text { 1.1 Recycling PET Bottles } \\
\text { \& Aluminum }\end{array}$ & 4 & -1 & 1 & 2 & 3 & 10 & 0 & 5 \\
\hline 1.2 Recycling Cans & 1 & 2 & 0 & 0 & 4 & 4 & 0 & 0 \\
\hline 2.1 Food Bank & 2 & 1 & 2 & 5 & 0 & 9 & 0 & 3 \\
\hline 2.2 Small Supplier & 1 & -2 & 1 & -1 & 0 & 5 & 0 & 0 \\
\hline $\begin{array}{l}2.3 \text { Sustainability } \\
\text { Information }\end{array}$ & 0 & 1 & 5 & -1 & 1 & 8 & 0 & 2 \\
\hline 3.1 Small Supplier (1) & 7 & 0 & 4 & 6 & 2 & 11 & 0 & 2 \\
\hline $\begin{array}{l}3.2 \text { Global Women } \\
\text { Empowering }\end{array}$ & 0 & -2 & 1 & 0 & 0 & 0 & 0 & 0 \\
\hline 4.1 CSR Annual Report & 3 & 3 & 1 & 0 & 0 & 7 & 1 & 3 \\
\hline 4.2 CSR Analysis & 3 & 2 & 0 & 0 & 1 & 7 & 1 & 0 \\
\hline $\begin{array}{l}\text { 4.3 Sustainable Investors } \\
\text { Relations }\end{array}$ & 1 & -1 & 0 & 1 & 0 & 11 & 0 & 1 \\
\hline $\begin{array}{l}5.1 \text { Cultural Promotion \& } \\
\text { Integration }\end{array}$ & 0 & -1 & 2 & -4 & 0 & 4 & 0 & 0 \\
\hline 5.2 Gender Equality & 1 & 1 & 1 & -4 & 0 & 4 & 0 & 2 \\
\hline 5.3 Disability & 4 & 4 & 4 & -3 & 0 & 4 & 3 & 4 \\
\hline 6.1 Food Bank (1) & -2 & -1 & -1 & -3 & 0 & 0 & 0 & 0 \\
\hline 6.2 Voluntary Work & 2 & 0 & 2 & 5 & 0 & 5 & 0 & 5 \\
\hline 6.3 Small Supplier (2) & 1 & -2 & 1 & -2 & 0 & 5 & 0 & 2 \\
\hline $\begin{array}{l}\text { *Small Suppliers } \\
\text { (aggregate) }\end{array}$ & 9 & -4 & 6 & 3 & 2 & 21 & 0 & 4 \\
\hline **Food Bank (aggregate) & 0 & 0 & 1 & 2 & 0 & 9 & 0 & 3 \\
\hline
\end{tabular}

Legend: The cell that holds the minimum value is coloured green, as they reflect SB (or negative SC). The cell that holds the 50th percentile (also known as median, middle value or midpoint) is coloured yellow, and the cell that holds the maximum value (21) is coloured red as it reflects the highest SC. All other cells are coloured proportionally.

Regarding possible areas of intervention, Setup and Execution SC are particularly significant within projects where operations are more involved (Recycling PET Bottles and Aluminum), where information needs to be collected and communicated effectively (Sustainability Information, Sustainable Investors Relations) or where multiple activities need to be coordinated (as in Small Suppliers).

\section{Discussion}

The application of Switching Cost analysis to the case study company allows to unveil important considerations to improve the business strategy. For instance, it is noted that Walmart Mexico and Central America experiences very high 'setup and execution' costs that require an intervention in order to improve CFP. The 'performance and time' costs and benefits are the same, suggesting the firm's ability to streamline the introduction of SDGs-oriented projects within the existing processes when considering the performance and time effects. In addition, while 'performance and time' and 'setup and execution' costs are present in almost all projects, 
other costs such as 'sunk' or 'search' are more specific to the nature of certain projects. It is also noted that projects requiring the substantial involvement of operations and the communication or coordination of multiple activities present with the highest SC. Finally, while projects create benefits in terms of relational and emotional impact in all the three ESG dimensions, they are negatively affected by procedural costs, particularly with respect to the governance and social dimension.

The applied SC analysis shows possible fields and directions to mitigate the internal impact of sustainability projects on the organisation in favour of CFP and a sustainable outcome, thus suggesting an approach to reduce the potential trade-off between sustainable activity and financial objectives. As a result, the methodology conducted in this study clarifies some dynamics of sustainable activity and its effects.

Moreover, by focusing on the firm's SC caused by sustainability projects, this paper rebalances the SC literature which, in recent decades, has been more focused on the strategic role of the consumers' SC. As per Porter's study (1985), the approach adopted in this study is believed to be equally important and complementary to the study of consumer SC, allowing for us to gain the formerly missing picture of SC analysis for business strategy improvements or development. In light of this, the active role that the firm can play in reducing the detected SC of SDGs-oriented projects is believed to contribute to CFP. This can be studied independently from the effect of other competitive factors.

Nonetheless, while the CFP resulting from the sustainability is difficult to assess, mainly due to the intangible effects that sustainability creates in the organisation, this paper provides a conceptual framework to unlock the knowledge of the effects through the use of SC perceptions.

The approach presented in this paper responds to the need for actionable tools to assess the effects of sustainability and making strategic decisions aimed to result in the achievement of both sustainability and CFP. In fact, the map presented in Section 5.3 allows us to highlight the firm's SC structure, thus suggesting areas of intervention for SC reduction in existing and future SDGs-oriented projects. This new strategy assessment methodology is applicable to any firm, independent of its sector or geography.

The study also sets the basis for potential new approaches to investment strategy analysis, particularly with regards to integrated analysis such as materiality. Indeed, the study of SC helps in terms of suggesting strengths and weaknesses in terms of resource allocation (internal investments) and the intangible effects of the sustainable activity (e.g. SDGs-oriented projects). This may potentially represent parameters for innovative ways of ranking or indexing, particularly in light of the relationship between ESG and SC. 


\section{Conclusions and research directions}

With the aim of aligning academic research to practice needs, this work has pioneered the research on SC analysis in relation to the implementation of sustainability in a corporate strategy. A framework has thus been developed in this paper to show how SC deriving from sustainable activity, specifically SDGs-oriented projects, has a double effect on ESG dimensions and CFP. The framework has then been applied to an embedded case study company in order to uncover the firm's SC structure and to understand its effects on both CFP and sustainability performance.

The chosen research design has allowed us to overcome important pitfalls in this study and in relation to application of switching costs, particularly regarding data definition and collection, for the application of the new conceptual framework and strategy assessment methodology as per the scope of this research. Nonetheless, looking at future literature advancements, the research focus can be shifted from the development of a corporate assessment methodology to its application for inferential purposes. For instance, involving a larger number of 'best-in-class' companies, the statistical analysis of SC can be allowed to set new benchmarks for the achievement of the dual objective of CFP and sustainability.

While the developed assessment methodology can be applied across multiple sectors and across all geographies, similar to materiality assessments, future studies may consider sectorlevel specificities. In addition, to collect a significant amount of data, the survey methodology can be developed from the findings of the semi-structured interviews conducted in this study.

Nevertheless, it is important to highlight that the proposed innovative analytical approach is complementary to the existing ones, firstly because of the intended isolation from the impact of competitive factors and secondly because, while using perceptions allows for the revelation of intangible factors, accountancy figures cannot be ignored in business strategy definitions. 


\section{Acknowledgements}

We are immensely grateful to the Sustainability Department at Walmart Mexico and Central America for collaborating to the project, and dedicating time and efforts to the cause of our research.

This research did not receive any special grant from funding agencies in the public, commercial, or not-for profit sectors. 


\section{REFERENCES}

Auerbach, C., Silverstein, L.B., 2003. Qualitative data: An introduction to coding and analysis. NYU Press.

Barroso, C., Picón, A., 2012. Multi-dimensional analysis of perceived switching costs. Ind. Mark. Manag., $\quad$ IMPASIA $2010 \quad$ 41, 531-543. https://doi.org/10.1016/j.indmarman.2011.06.020

Bhattacharya, A., 2013. Switching costs and sustained competitive advantage. Int. J. Bus. Manag. Invent. 2, 101-111.

Bocken, N.M.P., Short, S.W., Rana, P., Evans, S., 2014. A literature and practice review to develop sustainable business model archetypes. J. Clean. Prod. 65, 42-56. https://doi.org/10.1016/j.jclepro.2013.11.039

Bogner, A., Littig, B., Menz, W., 2009. Interviewing experts. ECPR.

Burnham, T.A., Frels, J.K., Mahajan, V., 2003. Consumer switching costs: A typology, antecedents, and consequences. J. Acad. Mark. Sci. 31, 109-126. https://doi.org/10.1177/0092070302250897

Byl, C.A.V. der, Slawinski, N., 2015. Embracing tensions in corporate sustainability: A review of research from win-wins and trade-offs to paradoxes and beyond. Organ. Environ. 28, 54-79. https://doi.org/10.1177\%2F1086026615575047

Caiado, R.G.G., Leal Filho, W., Quelhas, O.L.G., Luiz de Mattos Nascimento, D., Ávila, L.V., 2018. A literature-based review on potentials and constraints in the implementation of the sustainable development goals. J. Clean. Prod. 198, 1276-1288. https://doi.org/10.1016/j.jclepro.2018.07.102

Carroll, A.B., Shabana, K.M., 2010. The business case for corporate social responsibility: a review of concepts, research and practice. Int. J. Manag. Rev. 12, 85-105. https://doi.org/10.1111/j.1468-2370.2009.00275.x

Chebat, J.-C., Davidow, M., Borges, A., 2011. More on the role of switching costs in service markets: A research note. J. Bus. Res. 64, 823-829. https://doi.org/10.1016/j.jbusres.2010.10.003

Coase, R.H., 1937. The nature of the firm. Economica 386-405. https://doi.org/10.1111/j.14680335.1937.tb00002.x

Creswell, J.W., Creswell, J.D., 2018. Research design: Qualitative, quantitative, and mixed methods approaches, 5th ed. edition. ed. Sage Publications, Inc, Los Angeles.

Dam, L., Scholtens, B., 2015. Toward a theory of responsible investing: On the economic foundations of corporate social responsibility. Resour. Energy Econ. 41, 103-121. https://doi.org/10.1016/j.reseneeco.2015.04.008

de Ruyter, K., Wetzels, M., Bloemer, J., 1998. On the relationship between perceived service quality, service loyalty and switching costs. Int. J. Serv. Ind. Manag. 9, 436-453. https://doi.org/10.1108/09564239810238848

Easton, G., 2010. Critical realism in case study research. Ind. Mark. Manag., Case Study Research in Industrial Marketing 39, 118-128. https://doi.org/10.1016/j.indmarman.2008.06.004

Eccles, R.G., Ioannou, I., Serafeim, G., 2014. The impact of corporate sustainability on organizational processes and performance. Manag. Sci. 60, 2835-2857. https://doi.org/10.1287/mnsc.2014.1984

Eccles, R.G., Serafeim, G., 2013. The performance frontier: innovating for a sustainable strategy. Harv. Bus. Rev. 91, 50-+.

Ferrero-Ferrero, I., Fernandez-Izquierdo, M.A., Munoz-Torres, M.J., 2016. The effect of environmental, social and governance consistency on economic results. Sustainability 8, 1005. https://doi.org/10.3390/su8101005

Flick, U., von Kardoff, E., Steinke, I., 2004. A companion to qualitative research, SAGE Publications. ed. 
Fornell, C., 1992. A national customer satisfaction barometer: The Swedish experience. J. Mark. 56, 6-21. https://doi.org/10.1177/002224299205600103

Friedman, M., 1970. The social responsibility of business is to increase its profits. N. Y. Times Mag.

Friedman, M., 1962. Capitalism and Freedom. University of Chicago Press.

Funk, K., 2003. Sustainability and Performance. MIT Sloan Manag. Rev., Winter 44.

Given, L.M., 2008. The Sage Encyclopedia of Qualitative Research Methods. SAGE Publications.

Heide, J.B., Weiss, A.M., 1995. Vendor consideration and switching behavior for buyers in high-technology markets. J. Mark. 59, 30. http://dx.doi.org/10.2307/1252117

Hellmer, S., 2010. Switching Costs, switching benefits and lock-in effects - The regulated Swedish heat market. Energy Environ. 21, 563-575. https://doi.org/10.1260/0958305X.21.6.563

Hess, M., Ricart, J.E., 2003. Managing customer switching costs: A framework for competing in the networked environment. Manag. Res. 1, 93-110. https://doi.org/10.1108/15365430380000520

Hsu, C.-W., Lee, W.-H., Chao, W.-C., 2013. Materiality analysis model in sustainability reporting: a case study at Lite-On Technology Corporation. J. Clean. Prod. 57, 142151. https://doi.org/10.1016/j.jclepro.2013.05.040

Jones, M.A., Mothersbaugh, D.L., Beatty, S.E., 2002. Why customers stay: measuring the underlying dimensions of services switching costs and managing their differential strategic outcomes. J. Bus. Res. 55, 441-450. http://dx.doi.org/10.1016/S01482963(00)00168-5

Jones, M.A., Reynolds, K.E., Mothersbaugh, D.L., Beatty, S.E., 2007. The positive and negative effects of switching costs on relational outcomes. J. Serv. Res. 9, 335-355. https://doi.org/10.1177/1094670507299382

Khan, M., Serafeim, G., Yoon, A., 2016. Corporate Sustainability: First Evidence on Materiality. Account. Rev. 91, 1697-1624.

Klemperer, P., 1987. Markets with consumer switching costs. Q. J. Econ. 375-394. https://doi.org/10.2307/1885068

Lavrakas, P., 2008. Encyclopedia of Survey Research Methods. Sage Publications, Inc.

Ludeke-Freund, F., Dembek, K., 2017. Sustainable business model research and practice: Emerging field or passing fancy? J. Clean. Prod. 168, 1668-1678. https://doi.org/10.1016/j.jclepro.2017.08.093

Maas, K., Schaltegger, S., Crutzen, N., 2016. Advancing the integration of corporate sustainability measurement, management and reporting. J. Clean. Prod. 133, 859-862. https://doi.org/10.1016/j.jclepro.2016.06.006

Markman, G.D., Russo, M., Lumpkin, G.T., Jennings, P.D. (Dev), Mair, J., 2016. Entrepreneurship as a platform for pursuing multiple goals: A special issue on sustainability, ethics, and entrepreneurship. J. Manag. Stud. 53, 673-694. https://doi.org/10.1111/joms.12214

Monteverde, K., Teece, D.J., 1982. Supplier Switching Costs and Vertical Integration in the Automobile Industry. Bell J. Econ. 13, 206-213.

Nilssen, T., 1992. Two kinds of consumer switching costs. RAND J. Econ. 23, 579-589. https://doi.org/10.2307/2555907

Orlitzky, M., Schmidt, F.L., Rynes, S.L., 2003. Corporate social and financial performance: a meta-analysis. Organ. $\quad$ Stud. 403-441. https://doi.org/10.1177/0170840603024003910

Patterson, P.G., Smith, T., 2003. A cross-cultural study of switching barriers and propensity to stay with service providers. J. Retail. 79, 107-120.

Porter, M.E., 1985. The competitive advantage: creating and sustaining superior performance. The Free Press. 
Porter, M.E., 1980. Competitive Strategy: Techniques for Analyzing Industries and Competitors. The Free Press.

Porter, M.E., Kramer, M.R., 2002. The competitive advantage of corporate philanthropy. Harv. Bus. Rev. 80, 56-68, 133.

Samuelson, P.A., 1971. Love that corporation. Mt. Bell Mag.

Saunders, M., Lewis, P., Thornhill, A., 2015. Research Methods for Business Students, 7th ed.

Schaltegger, S., Burritt, R., 2018. Business cases and corporate engagement with sustainability: Differentiating ethical motivations. J. Bus. Ethics 147, 241-259. https://doi.org/10.1007/s10551-015-2938-0

Silva, S., Nuzum, A.-K., Schaltegger, S., 2019. Stakeholder expectations on sustainability performance measurement and assessment. A systematic literature review. J. Clean. Prod. 217, 204-215. https://doi.org/10.1016/j.jclepro.2019.01.203

Stankevičienè, J., Čepulytė, J., 2014. Sustainable value creation: Coherence of corporate social responsibility and performance of socially responsible investment funds. Econ. Res.Ekon. Istraživanja 27, 882-898. https://doi.org/10.1080/1331677X.2014.976058

Stole, L., 2007. Chapter 34 Price discrimination and competition, in: Amstrong, M., Porter (Eds.), Handbook of Industrial Organization. Elsevier, pp. 2221-2299.

Sullivan, K., Thomas, S., Rosano, M., 2018. Using industrial ecology and strategic management concepts to pursue the Sustainable Development Goals. J. Clean. Prod. 174, 237-246. https://doi.org/10.1016/j.jclepro.2017.10.201

Surroca, J., Tribo, J.A., Waddock, J.A., 2010. Corporate responsibility and financial performance: The role of intangible resources. Strateg. Manag. J. 31, 463-490. https://doi.org/10.1002/smj.820

Swanborn, P., 2010. Case Study Research: What, Why and How? SAGE.

Thompson, R.L., Cats-Baril, W., 2002. Information technology and management. McGrawHill.

Thomson

Reuters,

2019.

ESG

Score. https://www.refinitiv.com/content/dam/marketing/en_us/documents/methodology/esg -scores-methodology.pdf

Whitten, D., Wakefield, R.L., 2006. Measuring switching costs in IT outsourcing services. J. Strateg. Inf. Syst. 15, 219-248. https://doi.org/10.1016/j.jsis.2005.11.002

Williamson, O.E., 1981. The Economics of Organization: The Transaction Cost Approach. Am. J. Sociol. 87, 548-577. https://doi.org/10.1086/227496

Yin, R.K., 2018. Case study research and applications: design and methods, 6th ed. ed. SAGE, London.

Zollo, M., Cennamo, C., Neumann, K., 2013. Beyond what and why: Understanding organizational evolution towards sustainable enterprise models. Organ. Environ. 26, 241-259. https://doi.org/10.1177\%2F1086026613496433 